\title{
Effects of Water Stress on Symptomatology and Growth of Parthenocissus quinquefolia Infected by Xylella fastidiosa
}

\author{
Andrew J. McElrone, Department of Plant Biology, University of Maryland, College Park 20742; James L. \\ Sherald, National Park Service, National Capital Region, Center for Urban Ecology, Washington, D.C. 20007- \\ 4227; and Irwin N. Forseth, Department of Biology, University of Maryland
}

\begin{abstract}
McElrone, A. J., Sherald, J. L., and Forseth, I. N. 2001. Effects of water stress on symptomatology and growth of Parthenocissus quinquefolia infected by Xylella fastidiosa. Plant Dis. 85:1160-1164.

A greenhouse study was conducted to test the hypothesis that bacterial leaf scorch symptoms, caused by Xylella fastidiosa, are more severe during periods of drought stress. A two-by-two complete factorial design with two pathogen treatments (control and infected) and two soil moisture levels (high and low) was used with Parthenocissus quinquefolia vines in 1999 and 2000. In each year, a high percentage of $P$. quinquefolia plants inoculated with $X$. fastidiosa expressed typical bacterial leaf scorch symptoms, with the outer scorched portion of the leaf separated from green tissue by a chlorotic halo. X. fastidiosa was detected in all symptomatic plants using an immunomagnetic capture and nested polymerase chain reaction technique, and was reisolated and cultured in modified periwinkle wilt liquid media. In both years, symptoms progressed further along the stem and were more severe at corresponding leaf positions in lowwater-infected plants compared to high-water-infected plants. Total leaf area, shoot length, and number of nodes on the longest shoot per plant were all reduced due to drought and $X$. fastidiosa infection. This study is the first to verify the hypothesis that bacterial leaf scorch symptoms are enhanced during drought stress. Maintaining plant vigor with regular watering can be used to sustain plants infected by $X$. fastidiosa, particularly during periods of water stress.
\end{abstract}

Additional keywords: bacterial leaf scorch, drought, liana, Virginia creeper, xylem-limited bacteria

Xylella fastidiosa (37) is a xylem-limited bacterial plant pathogen that has a diverse and extensive host range encompassing at least 30 plant families (34). It is the causal agent of numerous scorching, scalding, and stunting diseases worldwide. Economically important diseases caused by $X$. fastidiosa include citrus variegated chlorosis $(2,11)$, Pierce's disease of grape (3), phony peach disease (38), alfalfa dwarf (8), periwinkle wilt (21), and leaf scorch of coffee (4), plum (29), pear (20), almond (23), mulberry (19), elm, oak, sycamore (12), maple (36), oleander (9), and pecan (30).

When present in agricultural and urban ecosystems, X. fastidiosa often occurs at high incidence and can be particularly

\section{Corresponding author: A. J. McElrone}

Email: mcelrone@wam.umd.edu

The completion of this project was made possible by financial support provided for A. J. McElrone's 2000 summer funding by the Behavior, Ecology, Evolution, and Systematics fellowship program at University of Maryland.

Accepted for publication 9 July 2001.

Publication no. D-2001-0824-02R

(C) 2001 The American Phytopathological Society devastating. In Brazil, where citrus variegated chlorosis limits citrus production, an estimated 68 million trees were diseased in 2000 (Bergamin-Filho, University of Sao Paulo, personal communication). On the National Mall in Washington, D.C., Sherald et al. (35) surveyed approximately 600 elms (Ulmus americana) and found that $30 \%$ of these trees were infected with $X$. fastidiosa. Additionally, Pierce's disease has long been considered the primary factor limiting development of the grape industry in Florida and other southeastern states in the United States (14).

In addition to the economically important hosts, numerous symptomatic and asymptomatic reservoir host plants have been identified in natural habitats surrounding crops $(5,16,22,28)$. The list of alternative hosts continues to grow as awareness of bacterial leaf scorch increases and as more precise molecular techniques are developed to detect $X$. fastidiosa. Transmission of bacteria from alternative reservoir hosts to susceptible, economically and aesthetically valuable hosts is considered a common occurrence in many agricultural and urban areas $(27,34)$. This transmission of $X$. fastidiosa from plant to plant is accomplished by xylem-feeding insects, including sharpshooter leafhoppers and spittlebugs (26).
No adequate control of infected plants is currently available; therefore, the removal of alternative hosts near susceptible crops is used as a management technique. For example, in California vineyards, alternative host plants growing along riparian zones and irrigation ditches are removed and subsequently replaced with "nonhosts" to reduce the spread of $X$. fastidiosa to grapevines (24). Although, in some habitats, the removal of alternative hosts is a viable option, in other areas this may not be a feasible management technique. For example, in the eastern United States, many alternative hosts are desirable ornamentals or native species endemic to the surrounding habitat $(16,22)$. Additionally, $X$. fastidiosa has such an extensive host range that it is unlikely that all potential hosts would be removed. Therefore, knowing how economically significant and alternative reservoir hosts are affected by $X$. fastidiosa is essential to developing a complete understanding of the disease dynamics and in guiding disease management.

Parthenocissus quinquefolia (L.) Planchon, (Virginia creeper), a deciduous liana native to North America, was found to be a symptomatic alternative host of $X$. fastidiosa in habitats surrounding agricultural systems in Florida (16). The natural distribution of $P$. quinquefolia ranges from Florida to as far north as southern Canada and west to Iowa, and it is generally abundant throughout this range (6). Its geographic range, combined with its common usage as an ornamental, provides ample opportunities in agricultural and urban systems for it to serve as a reservoir for transmission to susceptible crops and trees.

Several aspects of $X$. fastidiosa-caused diseases have received little attention experimentally. One such area is whether abiotic stress affects disease development. Several researchers have suggested that leaf scorch symptoms caused by $X$. fastidiosa become severe only after some other stress is placed on the host $(14,15,33)$. Hearon et al. (12) suggested that symptom development in mid- to late summer in urban trees was associated with seasonal moisture and heat stresses enhanced by the urban environment. Although studies have suggested that drought stress favors symptom development in bacterial leaf scorch, water limitation has never been used as a treatment in a con- 
trolled experiment. Therefore, we used a greenhouse study to test the hypothesis that leaf scorch symptoms caused by $X$. fastidiosa infection are more severe during periods of drought stress.

\section{MATERIALS AND METHODS}

We used a two-by-two complete factorial design, with two pathogen treatments (inoculated and control) and two water treatments (high and low), to determine the effect of drought stress and $X$. fastidiosa infection on growth and leaf scorch symptom development on $P$. quinquefolia. This experiment was initially performed during the summer of 1999 and was repeated in the summer of 2000. P. quinquefolia vines of equal age, produced from cuttings of nursery-grown plants, were watered regularly and maintained in pots under ambient greenhouse conditions prior to use in the experiments. Plants were fertilized with a standard liquid N-P-K fertilizer (20-10-20; Peters Fertilizer Products, Fogelsville, PA) recommended for container-grown woody ornamentals.

$P$. quinquefolia plants (approximately 10 to $20 \mathrm{~cm}$ in height) were inoculated with $X$. fastidiosa at one location near the stem base just above the soil using a scalpel incision method (31). Plants used in the summer 1999 experiment were inoculated in mid-July 1998, and plants used in the summer 2000 experiment were inoculated in mid-July 1999. A Pierce's disease strain of X. fastidiosa (strain \#92-8 obtained from Don Hopkins, University of Florida, Leesburg) was grown on a modified periwinkle wilt media and was then transferred to phosphate-buffered citrate magnesium (PBCM) solution. Inoculum was standardized in PBCM at an optical density (OD) of 0.07 to 0.10 at $560 \mathrm{~nm}\left(10^{7}\right.$ to $10^{8}$ cells/ml) with a Bausch \& Lomb Spectronic 710 spectrophotometer (31). Control plants also received scalpel incision inoculations but with sterile PBCM solution.

Plant samples were tested for the presence of $X$. fastidiosa using an immunomagnetic separation and nested polymerase chain reaction (PCR) technique $(22,25)$. Samples consisted of xylem fluid extracted with a microcentrifuge from $2-$ to $3-\mathrm{cm}$ stem segments or from plant sap obtained from macerated leaf petioles (22). This assay involves immunomagnetic separation of the bacteria from host tissue, followed by a two-step, nested PCR amplification using previously developed oligonucleotide primers specific to $X$. fastidiosa. This method is more reliable and sensitive than previous approaches (e.g., enzyme-linked immunosorbent assay), and allows for the detection of as few as five bacteria per sample (25). Additionally, X. fastidiosa was reisolated from all infected plants using liquid modified periwinkle wilt media. These cultures then were examined for diagnostic $X$. fastidiosa using phase contrast microscopy at $\times 400$ magnification.
Plants were watered to saturation once daily prior to the initiation of water treatments. Plants were then randomly assigned to either a high $(\mathrm{H})$ or low (L) soil moisture treatment. High-soil-moisture plants continued to be watered to saturation once daily throughout the experiment. Low-soil-moisture plants were watered to half of field capacity (determined gravimetrically) daily, except on cloudy days, when reduced transpiration alleviated the need for watering. Water treatments were initiated on 24 June in the summer of 1999 and on 11 July in the summer of 2000, and were sustained for 52 and 68 days, respectively.

Evaluation of plant responses included leaf scorch symptom analysis and several growth measurements. On 15 and $16 \mathrm{Au}-$ gust 1999, leaf area and the percentage of leaf area exhibiting scorch symptoms (including the chlorotic halo) were assessed for plants inoculated in 1998 using a photographic archive of leaves from each treatment. Scorch symptoms in P. quinquefolia progress from the plant base towards the apex (A. J. McElrone, personal observation); therefore, five leaf positions along the stem were chosen for disease assessment in order to span a basal to apical range. The most recent, fully expanded leaf was the most apical leaf sampled and corresponded with leaf position 0 . Moving toward the plant base, every fifth leaf was sampled, encompassing a total distance of 20 leaves. Photographs of leaves were made with a camera at a standard distance (approximately $0.5 \mathrm{~m}$ ) from the leaves. Leaves were positioned on engineering graph paper to facilitate calculating the area precisely while controlling for slight differences in camera position.

In the second trial on 17 September 2000, percentage of leaf area exhibiting scorching and growth parameters (total shoot leaf area, number of nodes, internode length, and total season shoot length) were measured for harvested $P$. quinquefolia plants. Leaf area for individual leaves at the same leaf positions (as described in the first trial) was measured using a Licor leaf area meter (model LI 3000A; Licor Inc. Lincoln, NE). Symptomatic sections of these leaves then were excised and measured with the leaf area meter. Percentage of leaf area scorched was calculated using (scorched area/total leaf area) $\times 100$. Total shoot leaf area, total seasonal shoot length, and the number of nodes were measured on the most prolific shoot on each plant at the conclusion of the experiment. Mean internode length was calculated by dividing the total seasonal shoot length by the number of nodes on this shoot for each of five replicates.

Analysis of variance (ANOVA) was computed using the SAS system (version 8.0, (1999; SAS Institute, Inc., Cary, NC). A repeated measures ANOVA was used to analyze the percentage of leaf area scorched to account for multiple measurements (five leaf positions on the same vine) on the same experimental unit. Data for each year were analyzed separately. Differences in means were analyzed using least-squares means (LS means) analysis for all parameters. All four possible treatment combinations were used with five replicates of each treatment in the two-by-two complete factorial design.

\section{RESULTS}

In each year, a high percentage of $P$. quinquefolia plants inoculated with $X$. fastidiosa expressed leaf scorching symptoms the following summer (46 out of 55 plants inoculated in 1999 exhibited symptoms in 2000; specific data not recorded for 1998 inoculations, but most inoculated plants exhibited symptoms). The outer scorched portion of the leaves was separated from the green tissue by a chlorotic halo typical of bacterial leaf scorch diseases caused by $X$. fastidiosa (Fig. 1). Symptoms were most severe on older leaves near the plant base and decreased in severity on more recently developed leaves near the plant apex. All $X$. fastidiosa-inoculated plants used in the experiments tested positive using the immunomagnetic and nested PCR detection technique. No

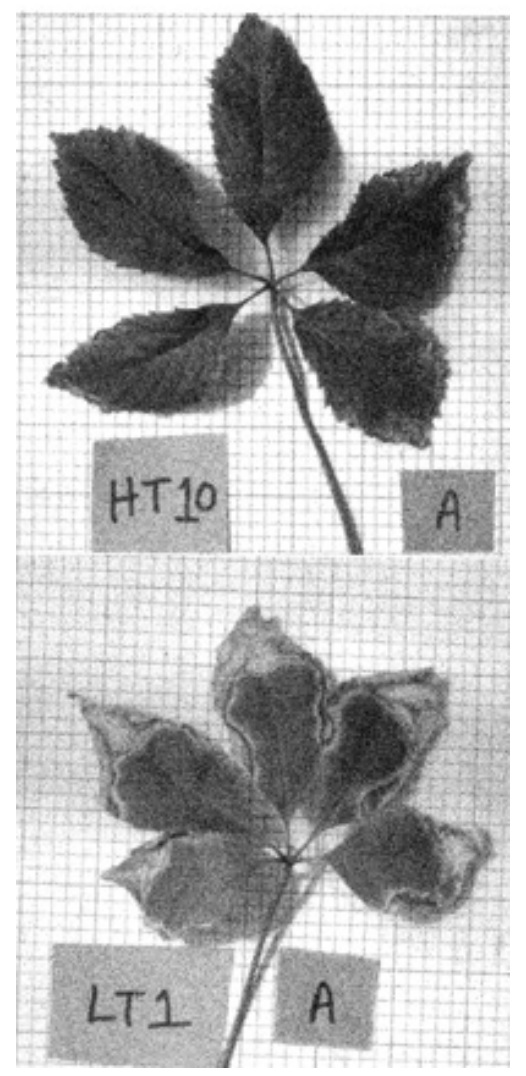

Fig. 1. Photographs of basally located leaves (position 20) used to calculate percentage of leaf area scorched from Parthenocissus quinquefolia infected by Xylella fastidiosa and concurrently drought stressed in the 1999 experiment. HT = high-water-infected (top photo); LT = low-water-infected (bottom photo). 
control plants tested positive for $X$. fastidiosa. Additionally, X. fastidiosa was reisolated and grown in modified periwinkle wilt liquid media from all infected plants exhibiting symptoms. The reisolated and cultured bacteria were observed under $\times 400$ phase contrast microscopy and matched the typical characteristics of $X$. fastidiosa grown in culture.

Leaf scorch symptoms were more severe on low-water-infected (LI) plants in both the 1999 and 2000 experiments (Figs. 1

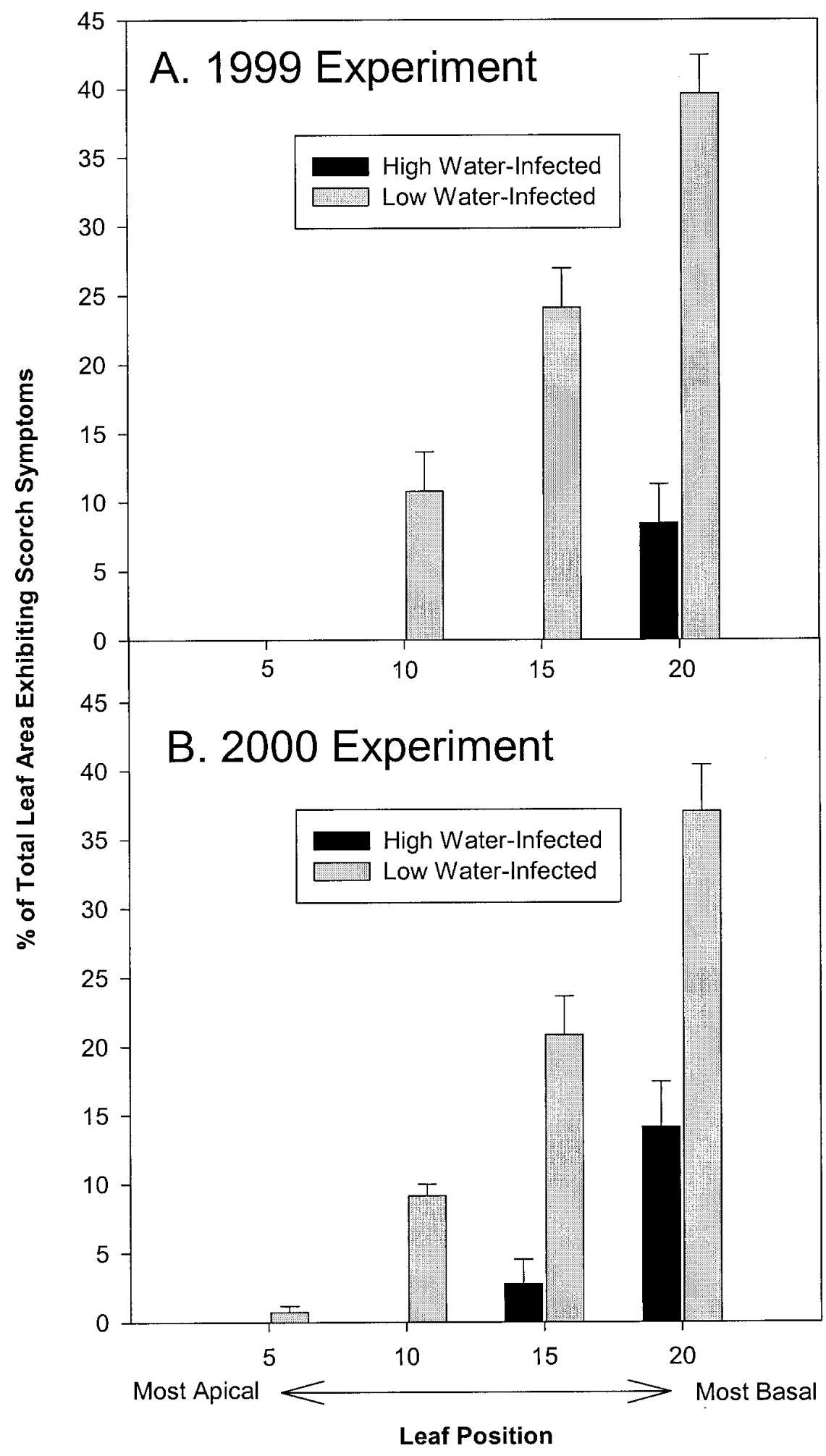

Fig. 2. Percentage of leaf area exhibiting scorch symptoms at five leaf positions for Xylella fastidiosa-inoculated plants only for the A, summer 1999 and B, summer 2000 experiments. No scorch symptoms were seen in control plants at any leaf position or in inoculated plants at leaf position $=0$ (most apical). Data are the mean \pm S.E.

and 2). In 1999, nearly $40 \%$ of LI leaf area exhibited scorching at the most basal leaf position (20), compared with only $8 \%$ for high-water-infected (HI) plants at this same leaf position $(P<0.0001$; Figs. 1 and 2A). Additionally, there was a significant soil moisture treatment-leaf position interaction $(P<0.0001$ from repeated measures analysis), with symptoms progressing further along the stem (scorching up to leaf position 10) in LI as compared with HI plants (no scorching at leaf positions 10 and 15). Similar results were found in 2000, with LI plants exhibiting more severe symptoms and symptoms progressing further along the stem compared with HI plants (Fig. 2B). Scorching was slightly higher in 2000 compared with 1999 for the HI plants, with $15 \%$ scorching at leaf position 20. Also, symptoms advanced an additional leaf position more apically for both HI and LI plants in 2000. No P. quinquefolia control plants, inoculated with PBCM only, showed symptoms.

In 1999, the water treatment had a significant impact on total leaf area (healthy and scorched) across all leaf positions with $\mathrm{H}$ plants having a greater area than $\mathrm{L}$ plants ( $P=0.02$; Fig. 3$)$. No differences were found between control (C) and infected (I) treatments when total leaf area was analyzed $(P>0.05)$. When only healthy leaf area (unscorched) was analyzed within each of the five positions, it was significantly reduced by the infection treatment at leaf position 20 for the 1999 experiment $(P=0.05$; data not shown).

In the 2000 experiment, all leaves from the largest shoot per plant were combined to calculate the total leaf area. This total shoot leaf area was significantly reduced by both $\mathrm{L}(P=0.001)$ and $\mathrm{I}(P=0.03)$ treatments (Table 1). Similarly, the total season shoot length and number of nodes were significantly reduced by $\mathrm{L}(P=0.001$ and $P=0.01$, respectively) and $\mathrm{I}(P=$ 0.004 and $P=0.05$, respectively) (Table 1 ). Internode length was not significantly different for any of the treatments $(P>$ $0.05)$, and there were no significant interaction effects for any of the parameters measured.

\section{DISCUSSION}

Hopkins and Adlerz (16) previously described $P$. quinquefolia as a symptomatic alternative host of $X$. fastidiosa in Florida; however, it had not been used in any experimental studies. Our study was the first attempt to mechanically inoculate $P$. quinquefolia and subsequently reisolate $X$. fastidiosa from symptomatic plants. Inoculations were successful approximately $84 \%$ of the time, resulting in symptoms typical of infections caused by $X$. fastidiosa in other hosts and reported on $P$. quinquefolia in Florida. The ease with which the host was infected suggests that $P$. quinquefolia may be highly susceptible and, because of its wide distribution, may be an important 
reservoir. It is not surprising that $P$. quinquefolia (family Vitaceae) is particularly susceptible to a Pierce's disease strain of $X$. fastidiosa because of its genetic relatedness and close similarities in growth form and habit with members of the genus Vitis (6). The ease and success of inoculation also show the potential of $P$. quinquefolia as an experimental host.

Several researchers $(12,14,15,33)$ had suggested that drought stress enhances symptom severity and progression in $X$. fastidiosa-infected hosts; however, no studies to date have empirically tested this hypothesis. To our knowledge, this is the first controlled experimental study to support this hypothesis. In both years of our study, leaf scorching symptoms of LI plants were more severe and progressed further along the stem compared with HI plants, suggesting that the abiotic water stress imposed by the lowwater treatment adds to the biotic water stress induced by the presence of the bacteria in the xylem conduits. Recommendations commonly made to growers experiencing problems with bacterial leaf scorch have included keeping the plant vigorous with regular watering and fertilization $(10,32,34)$; however, until this study, these recommendations have not been based on experimental evidence. No effective curative therapy is yet available; therefore, maintaining well-watered conditions, particularly when moisture is limiting, may help to slow the progression of the disease, reduce symptom severity, and extend the life of infected plants. This practice should be of particular importance in agricultural and urban settings where the plants are of value both economically and aesthetically.

Although results from both years were qualitatively similar, there were quantitative differences. Symptoms progressed further along the stem for both LI and HI plants in the 2000 experiment. We suspect that the extended duration of the drought treatment (65 days in 2000 compared with 52 days in 1999) allowed the symptoms to progress further along the stem due to an extended period of plant stress. Additionally, the end of the experiment in 2000 fell in mid-September compared with midAugust in 1999, which put the plants closer to the beginning of natural senescence. Changes in the hormonal balance of plants nearing the end of the growing season have been implicated in promoting bacterial leaf scorch symptom development. Hopkins (13) showed that changes in the hormonal balance of the plants, particularly increases in abscisic acid, can enhance symptom development in grapes.

In the 1999 experiment, leaf area for individual leaves was reduced by drought but not by $X$. fastidiosa infection. Kostka et al. (18) found similar results with American elm trees in which leaf size was not affected by $X$. fastidiosa infection. However, in both studies, the amount of healthy tissue per leaf was reduced for leaves with significant scorching. Additionally, when we analyzed the total leaf area for the whole shoot in the 2000 experiment, it was reduced by both drought stress and $X$. fastidiosa infection. The growth habit of $P$. quinquefolia puts a premium on internode length, presumably to aid in climbing and finding trellis support, and to space leaves and reduce selfshading, and we found no significant differences in this parameter. By maintaining internode length, even when shoot lengths are reduced, the resultant shoots produce fewer nodes. $P$. quinquefolia typically produces one leaf per node, and thus the reduction of total leaf area that we found resulted primarily from fewer nodes being produced per shoot.

Goodwin et al. (7) showed that symptomatic leaves on grapevines infected with Pierce's disease had reduced stomatal conductance and photosynthesis, which is also a common response of water-limited plants (17). For $X$. fastidiosa-infected plants, the further reduction in photosynthate production (reduced leaf area and stomatal closure) induced by drought probably impairs the plant's ability to defend against or continue growth ahead of the advancing bacteria. Boyer (1) proposed the following two mechanisms to explain how water stress increases the susceptibility of plants to attack by pathogens: (i) reduced photosynthate production induced by drought eliminates the plant's ability to produce defensive compounds or (ii) plant growth is reduced without reducing the pathogen's ability to reproduce, thus allowing further progression and increased symptom severity in the host (1). Whether one or both of these mechanisms form the basis of the observed enhancement of disease symptomology and progression in our system is yet to be determined.

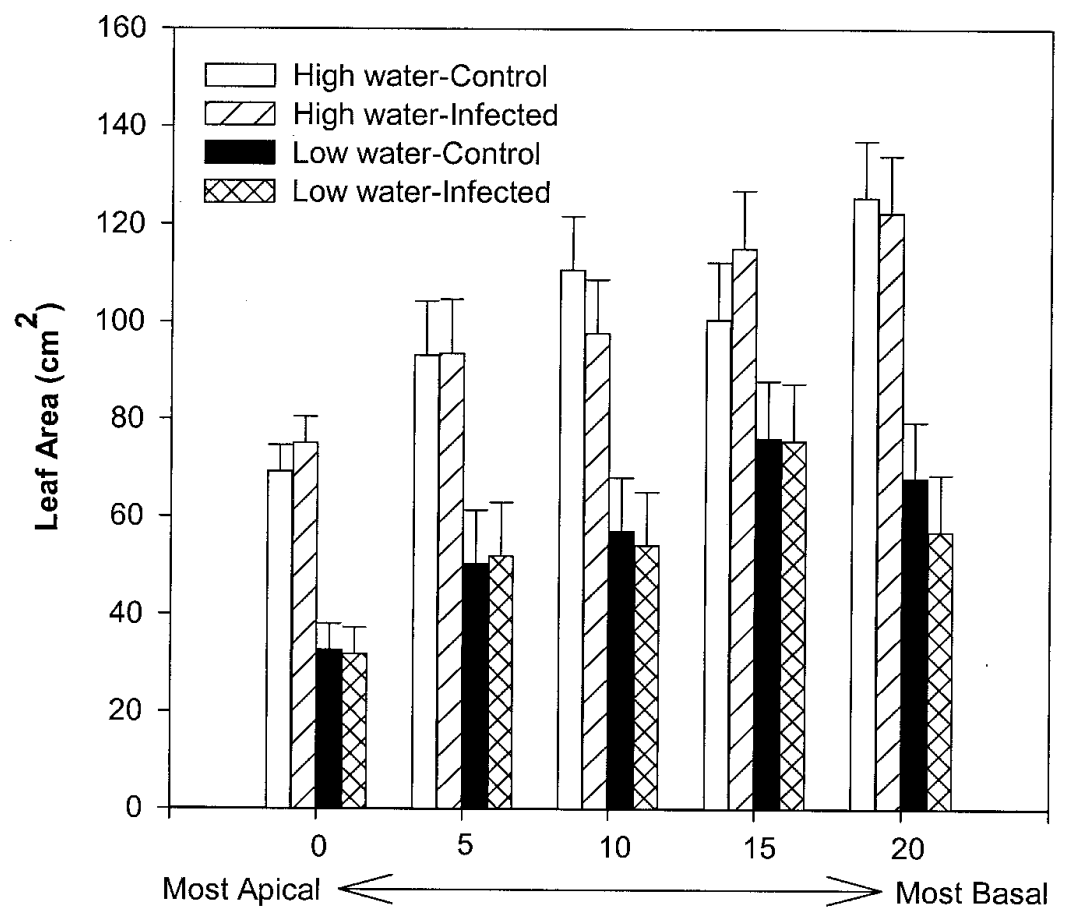

\section{Leaf Position}

Fig. 3. Parthenocissus quinquefolia leaf area for one leaf per plant at each of the five positions along the stem. Data are from the 1999 experiment and include tissue exhibiting scorching as well as healthy tissue. Data are mean \pm S.E.

Table 1. Total leaf area for whole shoot, total season shoot length, mean internode length, and mean number of internodes on the longest shoot for Parthenocissus quinquefolia infected by Xylella fastidiosa from the 2000 experiment $^{2}$

\begin{tabular}{lcccc}
\hline Treatment & $\begin{array}{c}\text { Leaf area } \\
\left(\mathbf{c m}^{\mathbf{2}}\right)\end{array}$ & $\begin{array}{c}\text { Shoot length } \\
(\mathbf{c m})\end{array}$ & $\begin{array}{c}\text { Internode } \\
\text { length } \mathbf{( c m})\end{array}$ & $\begin{array}{c}\text { Number of } \\
\text { nodes }\end{array}$ \\
\hline High water, control & $10,994 \mathrm{a}$ & $643 \mathrm{a}$ & $7.1 \mathrm{a}$ & $92 \mathrm{a}$ \\
High water, infected & $7,876 \mathrm{~b}$ & $532 \mathrm{a}, \mathrm{b}$ & $7.5 \mathrm{a}$ & $71 \mathrm{~b}$ \\
Low water, control & $4,625 \mathrm{~b}, \mathrm{c}$ & $455 \mathrm{~b}$ & $7.2 \mathrm{a}$ & $64 \mathrm{~b}, \mathrm{c}$ \\
Low water, infected & $2,144 \mathrm{c}$ & $331 \mathrm{c}$ & $6.4 \mathrm{a}$ & $52 \mathrm{c}$ \\
\hline
\end{tabular}

${ }^{\mathrm{z}}$ Data are the mean of five reps. Within a parameter column, means followed by the same letter are not significantly different $(P=0.05)$ based on the least-squares means (LS means) test. 


\section{ACKNOWLEDGMENTS}

We thank D. Hopkins (University of Florida, Leesburg) for supplying us with a Pierce's Disease strain of X. fastidiosa; M. Pooler (U.S. National Arboretum) for providing access to her lab to run the PCR analyses of plant samples; I. Castellanos and P. Baldauf for technical assistance; and A. Grybauskas and two anonymous reviewers for their critical reviews of this manuscript.

\section{LITERATURE CITED}

1. Boyer, J. S. 1995. Biochemical and biophysical aspects of water deficits and the predisposition to disease. Annu. Rev. Phytopathol. 33:251-274.

2. Chang, C. J., Garnier, M., Zreik, L., Rossetti, V., and Bove, J. M. 1993. Culture and serological detection of xylem-limited bacterium causing citrus variegated chlorosis and its identification as a strain of Xylella fastidiosa. Curr. Microbiol. 27:137-142.

3. Davis, M. J., Purcell, A. H., and Thomson. S. V. 1978. Pierce's disease of grapevines: isolation of the causal bacteria. Science 199:75-77.

4. deLima, J. E. O., Miranda, V. S., Hartung, J. S., Brlansky, R. H., Coutinho, A., Roberto, S. R., and Carlos, E. F. 1998. Coffee leaf scorch bacterium: axenic culture, pathogenicity, and comparison with Xylella fastidiosa of citrus. Plant Dis. 82:94-97.

5. Freitag, J. H. 1951. Host range of the Pierce's disease virus of grapes as determined by insect transmission. Phytopathology 41:920934.

6. Gleason, H. A., and Cronquist, A. 1991. Manual of Vascular Plants of Northeastern United States and Adjacent Canada. The New York Botanical Garden, Bronx, NY.

7. Goheen, A. C., Nyland, G., and Lowe, S. K. 1973. Association of a rickettsia-like organism with Pierce's disease of grapevines and alfalfa dwarf and heat therapy of the disease in grapevines. Phytopathology 63:341-345.

8. Goodwin, P. H., DeVay, J. E., and Meredith, C. P. 1988. Physiological responses of Vitis vinifera $\mathrm{cv}$. 'Chardonnay' to infection by the Pierce's disease bacterium. Physiol. Mol. Plant Pathol. 32:17-32.

9. Grebus, M. E., Henry, J. M., Hartin, J. E., and Wilen, C. A. 1996. Bacterial leaf scorch of oleander: a new disease in southern California. (Abstr.) Phytopathology 86:S110.

10. Hartman, J. 1999. Shade trees and ornamentals: Oak bacterial leaf scorch affected by drought. Ky. Pest News 27 September 1999.

11. Hartung, J. S., Beretta, J., Brlansky, R. H., Spisso, J., and Lee, R. F. 1994. Citrus variegated chlorosis bacterium: axenic culture, pathogenicity, and serological relationships with other strains of Xylella fastidiosa. Phytopathology 84:591-597.

12. Hearon, S. S., Sherald, J. L, and Kostka, S. J. 1980. Association of xylem-limited bacteria with elm, sycamore, and oak leaf scorch. Can. J. Bot. 58:1986-1993.

13. Hopkins, D. L. 1985. Effects of plant growth regulators on development of Pierce's disease symptoms in grapevine. Plant Dis. 69:944946.

14. Hopkins, D. L. 1989. Xylella fastidiosa: xylem-limited bacterial pathogens of plants. Annu. Rev. Phytopathol. 27:271-290.

15. Hopkins, D. L. 1995. Xylella fastidiosa. In: Pathogenesis and Host Specificity in Plant Diseases: Histopathological, Biochemical, Genetic, and Molecular Bases. Vol. 1: Prokaryotes. U. S. Singh, R. P. Singh, and K. Kohmoto, eds. Elsevier Science, Inc., New York.

16. Hopkins, D. L., and Adlerz, W. C. 1988. Natural hosts of Xylella fastidiosa in Florida. Plant Dis. 72:429-431.

17. Hsiao, T. C. 1973. Plant responses to water stress. Annu. Rev. Plant Physiol. 24:519-570.

18. Kostka, S. J., Tattar, T. A., and Sherald, J. L. 1986. Elm leaf scorch: abnormal physiology in American elms infected with fastidious, $x y-$ lem-inhabiting bacteria. Can. J. For. Res. 16:1088-1091.

19. Kostka, S. J., Tatter, T. A., Sherald, J. L., and Hurtt, S. S. 1986. Mulberry leaf scorch, new disease caused by a fastidious, xylem-inhabiting bacterium. Plant Dis. 70:690-693.

20. Leu, L. S., and Su, C. C. 1993. Isolation, cultivation, and pathogenicity of Xylella fastidiosa, the causal bacterium of pear leaf scorch disease. Plant Dis. 77:642-646.

21. McCoy, R. E., Thomas, D. L., Tsai, J. H., and French, W. J. 1978. Periwinkle wilt, a new disease associated with xylem delimited rickettsialike bacteria transmitted by a sharpshooter. Plant Dis. Rep. 63:1022-1026.

22. McElrone, A. J., Sherald, J. L., and Pooler, M. R. 1999. Identification of alternative hosts of Xylella fastidiosa in the Washington, D.C. area using a nested polymerase chain reaction (PCR). J. Arboric. 25(5):258-263.

23. Mircetich, S. M., Lowe, S. K., Moller, W. J., and Nyland, G.. 1976. Etiology of the almond leaf scorch disease and transmission of the causal agent. Phytopathology 66:17-24

24. Pierce's Disease/Riparian Habitat Workgroup. 2000. Information Manual: Riparian Vegetation Management for Pierce's Disease in North Coast California Vineyards. University of California, Davis.

25. Pooler, M. R., Myung, I. S., Bentz, J., Sherald, J., and Hartung, J. S. 1997. Detection of Xylella fastidiosa in potential insect vectors by immunomagnetic separation and nested polymerase chain reaction. Lett. Appl. Microbiol. 25:123-126.

26. Purcell, A. H. 1995. Transmission and epidemiology. In: Xylella fastidiosa and Associated Diseases. J. L. Sherald and A. B. Gould, eds. Plant Diagn. Q. 16(3):111-115.

27. Purcell, A. H., and Saunders, S. R. 1999. Fate of Pierce's Disease strains of Xylella fastidiosa in common riparian plants in California. Plant Dis. 83:825-830.

28. Raju, B. C., Goheen, A. C., and Frazier, N. W. 1983. Occurrence of Pierce's Disease bacteria in plants and vectors in California. Phytopathology 73:1309-1313.

29. Raju, B. C., Wells, J. M., Nyland, G. Brylansky, R. H., and Lowe, S. K. 1982. Plum leaf scald: isolation, culture, and pathogenicity of the causal agent. Phytopathology 72:1460-1466.

30. Sanderlin, R. S., and Heyderich-Alger, K. I 2000. Evidence that Xylella fastidiosa can cause leaf scorch disease of pecan. Plant Dis. 84:1282-1286.

31. Sherald, J. L. 1993. Pathogenicity of Xylella fastidiosa in American elm and failure of reciprocal transmission between strains from elm and sycamore. Plant Dis. 77:190-193.

32. Sherald, J. L. 1995. Leaf scorch of amenity trees. In: Xylella fastidiosa and Associated Diseases. J. L. Sherald and A. B. Gould, eds. Plant Diagn. Q. 16(3):119-123.

33. Sherald, J. L., Hearon, S. S., Kostka, S. J., and Morgan, D. L. 1983. Sycamore leaf scorch culture and pathogenicity of fastidious xylemlimited bacteria from scorch-affected trees. Plant Dis. 67:849-852.

34. Sherald, J. L., and Kostka, S. J. 1992. Bacterial leaf scorch of landscape trees caused by Xylella fastidiosa. J. Arboric. 18(2):57-63.

35. Sherald, J. L., Patton, E. N., Stidham, T. M. and Favre, C. L. 1994. Incidence and development of bacterial leaf scorch of elm on the National Mall. J. Arboric. 20(1):18-23.

36. Sherald, J. L., Wells, J. M., Hurtt, S. S., and Kostka, S. J. 1987. Association of fastidious, xylem-inhabiting bacteria with leaf scorch in red maple. Plant Dis. 71:930-933.

37. Wells, J. M., Raju, B. C., Hung, H. Y., Weisburg, W. G., Mandelco-Paul, L., and Brenner, D. J. 1987. Xylella fastidiosa: gram-negative xylem-limited, fastidious plant bacteria related to Xanthomonas. Int. J. Syst. Bacteriol. 37:136-143.

38. Wells, J. M., Raju, B. C., and Nyland, G. 1983. Isolation, culture, and pathogenicity of the bacterium causing phony disease of peach. Phytopathology 73:859-862. 